THURSDAY, JANUARY I, I880

\section{GEOLOGICAL SURVEY OF THE UNITED STATES}

$T^{T}$ will be in the recollection of geological readers that the chronic feuds to which so many independent United States Government Surveys with rival objects and officers gave rise, were last year referred by Congress to the National Academy of Sciences, and that, acting on the Report submitted by the Academy, Congress determined to abolish all the separate geological and geographical surveys then in existence under different Departments, and to consolidate the work under one establishment, to be termed the United States Geological Survey. In order, however, that the work already in progress might not be wholly lost or indefinitely postponed it was enacted that for the preparation and completion of the reports, maps, and other work of the Geological and Geographical Survey of the Territories, of the Geographical and Geological Survey of the Rocky Mountain Region, and of the Geographical Surveys West of the rooth Meridian under the direction of the Secretary of War, the sum of twenty thousand dollars, to be immediately available, should be given to each of these three offices. It is to be hoped that these provisions will suffice for the publication of several valuable memoirs which are known to have been in progress for some years.

One of the recommendations made by the Academy of Sciences was that a separate organisation should be provided for the surveys of mensuration, including the purely geographical and topographical work such as had been carried on by the Coast and Ceodetic Surveys and the Land Office. For this fundamentally important and indispensable branch of the scientific examination of the country no special provision was, however, made by Congress; which is all the more to be regretted seeing that by the terms of the Act, so far as we can make out, the Engineer bureau was to be relieved of the important geodetic work it had so long and so ably been conducting west of the rooth meridian. There are ways indeed of driving a carriage and four through an Act of Congress, and the Engineers have shown themselves so able to hold their own under many successive administrations, that we wait with some interest to learn how far exactly their operations will be curtailed or modified.

The Act which constituted the new organisation of the Geological Survey likewise made provision for a Commission on the codification of the laws relating to the Survey and disposition of the Public Domain. Of this Commission the Director of the United States Geological Survey was ex officio appointed a member. The Commission began its work last summer in the Western Territories, and made rapid progress. Besides Mr. Clarence King, it included among its members Major Powell and Capt. Dutton, who have so long been known for their geological labours among the great plateaux and Canons of the West. Doubtless the objects of the Commission were of paramount importance, and these three geologists, from their long and intimate knowledge of the Territories, were probably better fitted than any other citizens for carrying out rapidly and exhaustively VCL. XXI. -No. 53I the special inquiries entrusted to them. Otherwise some natural regret might be expressed that the services of such men should have been removed for practically a year from the geological work for which they have proved themselves so eminently qualified.

It is an excellent custom in the United States to define the time within which a Commission appointed by Congress is to send in its Report. This inquiry into the Land Laws and the classification of public lands was required to be completed within a year from the organisation of the Commission. We hear that the work is now finished so far as collecting evidence goes, and that the Report on the whole subject may shortly be expected. How long would a Royal Commission of similar nature and scope have lasted here?

The cessation of the labours of the Commission will free the geologists for the work of the Geological Survey. Much interest is felt as to the distribution of their staff and the areas over which it will be extended. Certainly no corps of geologists ever had a more magnificent opportunity of adding to the temple of science. They have large funds at their disposal, boundless territory, ground of surpassing geological interest, and the enormous advantage of a previous experience of many years spent in the West Ther agans the a tehed with particular dare and evan with soine anxiety in the eastern States, owing to a curious episode after the passing of the Act establishing the Geological Survey. Subsequent to the appointment of the Director of the new organisation, an extra Session of Congress was held, in which a resolution was passed in the House of Representatives to the effect "that the Director may extend his examinations into the States." As this resolution was adopted on June 29 and the Session closed next day, there was not time to bring it before the Senate.

It will be seen that the addition of these words enormously widens the area of the Director's jurisdiction. As Prof. Dana complains, this area is " suddenly enlarged to the dimensions of the whole country from the Atlantic to the Pacific," and he adds that this was the view of the director himself, who had personally informed him "that it was his purpose under the Act, to send a party into New England next spring." We can hardly suppose that any such vast extension of the original scope of the Geological Survey was present to the minds of the representatives who passed the resolution. The additional words were probably meant only to authorise the work of the Survey to be prolonged into States adjoining the Territories, to such an extent as the necessities or advantages of the service might require. And this was a very proper addition. Geological boundary lines have seldom any close relation to political ones, even when physieal features are used as lines of demarcation. But in America, where the limits of States and Territories are defined by meridians and parallels, it would be absurd to arrest a geologist's work in the middle of a prairie, or a cañon, or a mountain-range, because he had reached the limiting but invisible boundary of his territory. The idea of sending a party into New England looks-like a joke, and as such we shall believe it to have been intended until authentic news of the arrival of the Survey party actually reaches this country. That it is not so regarded in the United States, however, is manifest by the flutter 
into which the geologists of the Eastern States have been thrown. We hear of the scheme being stigmatised as another example of the infringement of State rights, of the illegal assumption of State responsibilities, and of the danger to private interests as well as public morality to be apprehended from the temptations which such a vastly extended supervision would put in the way of the central authority.

The area in the West yet to be explored is so vast, the problems offered by it so numerous and so tempting, the field so free from "vested interests" of any previous explorers, that we cannot for a moment imagine that $\mathrm{Mr}$. Clarence King and his associates, who, having already cleared a way for themselves through that wide West, know better than any other men its infinite variety and attractiveness, will trouble themselves with the geology of the East, where for generations past the labourers have been so many, and where, comparatively speaking, the field is so small and already so well tilled. With the humour of their countrymen they may have made use of the rather indefinite language of a congressional resolution to scare their less adventurous brethren in the Eastern cities. We would, therefore, counsel the geologists of the East to treat the matter as a joke. They have nothing to fear. It would be as absurd to give the Director of the United States Geological Survey control over the geology of all the States, as to make the Chief Constable of New York comptroller of morals for the whole of the Union.

A. G.

\section{SAHARA AND SUDAN}

Saharâ und Sudan Ergebnisse sechsjähriger Reisen in Africa. Von Dr. Gustav Nachtigal. Erster Theil, mit 49 Holzschnitten und 2 Karten. (Berlin, 1879.)

$\mathrm{D}^{\mathrm{n}}$ RACHTIGAL'S wanderings came to an end more than six years ago. Most of his results have been brought at various times before learned societies and otherwise published, and the most important parts of his route are laid down in published atlases. The present work contains a detailed account of his entire travels and observations. The book now under consideration is only an instalment extending over his journey up to the end of the year 1870 ; a second is to follow. The volume is a large octavo of 750 closely printed pages with an appendix containing meteorological observations.

Dr. Nachtigal undertook the duty of conveying to the Sultan of Bornu, the country surrounding Lake Tsad, a present sent by the Emperor of Germany in acknowledgment of the hospitality and assistance afforded by the Sultan to the German travellers, Barth and Overweg, Vogel, von Beurman, and Rohlfs. In his journey from Tripolis to Bornu the author passed along the caravan route traversed before by Denham and Clapperton in 1822-23-24, and by Barth and Vogel in 1849-55, and also by Rohlfs. During all this portion of his journey he was therefore on ground comparatively well-known from the writings of the above travellers. He made however three long excursions to the eastward, one into Tibesti or $\mathrm{Tu}$, another to Borku, and a third into Bagirmi to the south of Lake Tsad; finally he made his way eastward from Lake Tsad across Wadai and Darfor, to Chartum.

Of the present volume more than two-thirds is occupied with the account of the journey along the direct route between Tripolis and Bornu, and an account of Fezzan, and of Bornu and its capital, Kuka. The remaining third of the book relates to the journey into the unexplored region of Tibesti and is thus the most interesting and important portion of the work.

Lake Tsad lies almost due south of Tripolis and the caravan route follows an almost straight line between the

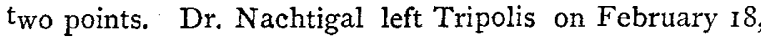
I869, and after his wanderings in Tibesti and many mishaps reached Kuka in June 1870 . At Tripolis, and also in Murzuq he frequently met with the well-known traveller, Miss Tinne, of whose history and deplorable murder by the Tuaric he gives a full account. Miss Tinne or "the King's Daughter," as she was called by the inhabit ants of the country, excited the greatest curiosity and was believed to possess supernatural powers. One story circulated about her at Murzuq was to the effect that her large pet dog which travelled with her was a bewitched man and changed into the human form from time to time.

The fourth chapter deals with the natural characteristics of the district of Fezzan. So scarce and dear are mutton and goats' flesh in Fezzan that recourse is had to minute crustacea and the larva of diptera from lakes of brackish water as food. The Bahâr-el-Dûd, or "worm lake," is so full of the larvæ and of the crustacea, the cosmopolitan inhabitant of salt water lakes, Artemia, that the inhabitants collect these arimals in masses and knead them up with dates and an alga which also grows in the lake to form a repast which is highly esteemed. An Artemia occurs in the Great Salt Lake in Utah; the species in the present case is $A$. Oudneyi.

A long chapter on the climate and diseases of Fezzan follows, in which the maladies are described with an amount and character of detail which, though highly valuable, is perhaps more befitting a strictly medical publication than a general book on travel with a more or less popular aim. Similar medical details are given throughout the book and sometimes seem very much out of place. The native notions of medical treatment are curious and primitive. Thus patients suffering from cancer of the breast must most carefully abstain from all food derived from animals provided with tails, even such as milk and butter. To promote fruitfulness in women young suckling hares are prescribed No one in Fezzan doubts that it is possible for a child to remain dormant within the mother for years or even for ever and this theory is most conveniently made use of when mishap necessitates it by wives whose-husbands have been absent on very long journeys. As an aphrodisiac the fat of a Manatee, Manatus Vogellii, is used. The drug is sold at a high price being brought from the River Binuie a tributary of the Kowara in which the animal is abundant. Diseases are believed to be caused either by evil spirits or by the action of the evil eye.

During his exploration of Tibesti Dr. Nachtigal experienced many dangers and difficulties, losing his way, and suffering from want of water and forced night marches. A very interesting account is given of the ceremonials observed by the Tubu people in greeting one another. A most elaborate performance is gone through when two strangers meet in this wild country. Each of 